\title{
Lues maligna in an HIV-infected patient
}

\author{
Lues maligna em um paciente com infecção pelo HIV
}

\author{
Luiz Fernando Cabral Passoni' ${ }^{1}$, Jacqueline Anita de Menezes ${ }^{1}$, Sayonara Rocha Ribeiro ${ }^{1}$ \\ and Érica Coutinho O. Sampaio ${ }^{1}$
}

\begin{abstract}
We report such a case of malignant syphilis in a 42-year-old HIV-infected man, co-infected with hepatitis B virus, who presented neurolues and the classical skin lesions of lues maligna. The serum VDRL titer, which was 1:64 at presentation, increased to 1:2,048 three months after successful therapy with penicillin, decreasing 15 months later to 1:8.
\end{abstract}

Key-words: Malignant syphilis. Lues maligna. Neurolues. HIV infection.

\section{RESUM0}

Descrevemos um caso de sífilis maligna em um paciente de 42 anos com infecção pelo HIV e pelo vírus da hepatite B. 0 paciente, com lesões cutâneas clássicas de lues maligna e VDRL positivo no soro e no líquor, teve uma resposta excelente ao tratamento com penicilina cristalina. O VDRL sérico, que no diagnóstico era de 1:64, aumentou três meses depois para 1:2.048 e diminuiu para 1:8 após 15 meses.

Palavras-chaves: Sífilis maligna. Lues maligna. Neurolues. Infecção HIV.

Lues maligna is a rare ulcerative form of secondary syphilis characterized by papulopustular skin lesions that rapidly enlarge and evolve into round or oval ulcers with sharp borders, centrally covered by a dark, sometimes rupioid crust ${ }^{6}$. Lesions in various stages of development confer a pleomorphic picture. Mucous membranes of the mouth and nose may be involved, and prodromes of fever, headache, and myalgia are common ${ }^{614}$. Although its incidence had been decreasing since the beginning of the $20^{\text {th }}$ Century, the number of reported cases has increased after 1988, most occurring in patients with HIV infection. We describe a case of malignant syphilis in an HIV-infected patient, the third diagnosed at the Infectious Diseases Department of the Hospital dos Servidores do Estado, Rio de Janeiro, Brazil, from 1986-2002. Previously, in April 1989 and January 1993, respectively, a 43-year-old bisexual man and a 44-year-old homosexual man presented with lues maligna as their first manifestation of HIV-infection ${ }^{12}$.

\section{CASE REPORT}

In June 1999, a 42-year-old homosexual male presented with a two-week history of multiple erythematous papules on his face, trunk and extremities, which progressed to pustules and crusted ulcers. All lesions were painless and he denied having any systemic symptoms.

He was advised that he was HIV-positive in June 1995, when he was seen for evaluation of spleen enlargement and anemia. At that time, laboratory investigations revealed a positive serology for both HIV (ELISA and Western-Blot) and HTLV I/II infection. Serology for hepatitis B showed the presence of HBsAg and $\mathrm{HBCAb}$, whereas serology for hepatitis $\mathrm{C}$ was negative. A liver biopsy was refused and he was lost to follow-up until June 1996, when he sought medical assistance presenting clinical features of liver failure and hypersplenism. Six months later his $\mathrm{CD}^{+}$cell count was $242 / \mathrm{mm}^{3}$ (20\%), but he refused to use antiretroviral drugs, which were begun only in May 1998. At that time, his $\mathrm{CD} 4^{+}$cell count was $404 / \mathrm{mm}^{3}(34 \%)$ and his HIV viral load 5,800 copies/ml ( nucleic acid sequence based amplification, NASBA) . Six weeks after starting stavudine and lamivudine, CD4 ${ }^{+}$ count increased to $494 / \mathrm{mm}^{3}$ (59\%) and viral load dropped to undetectable levels ( $<400$ copies/ml). He had been taking the medicines regularly until two months before the appearance of the skin lesions, when he discontinued the antivirals.

On examination the patient appeared underweight. He was pale and afebrile. Skin lesions consisted of multiple erythematous

1. Serviço de Doenças Infecciosas e Parasitárias do Hospital dos Servidores do Estado, Rio de Janeiro, RJ, Brasil.

Address to: Dr. Luiz Fernando Cabral Passoni. R. Mal Mascarenhas de Morais 191/1007, Copacabana, 22030-040 Rio de Janeiro, RJ, Brasil.

Tel: 5521 2518-1594

e-mail: lfpassoni@ig.com.br

Recebido para publicação em 21/5/2003

Aceito em 19/11/2004 

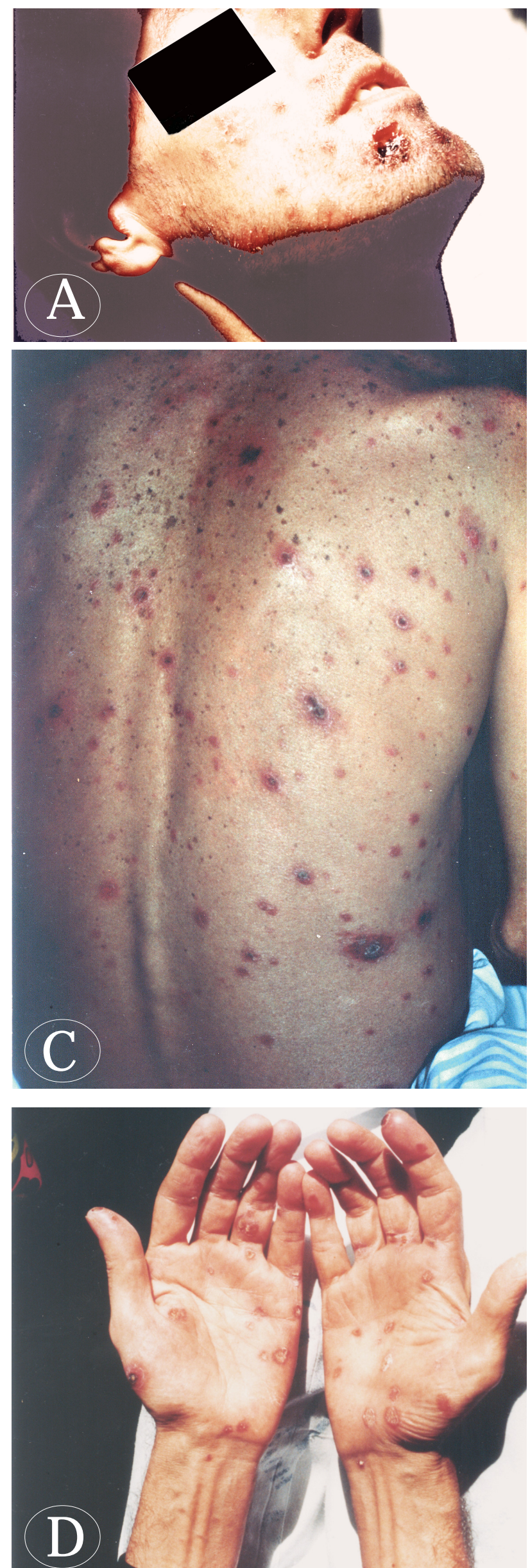
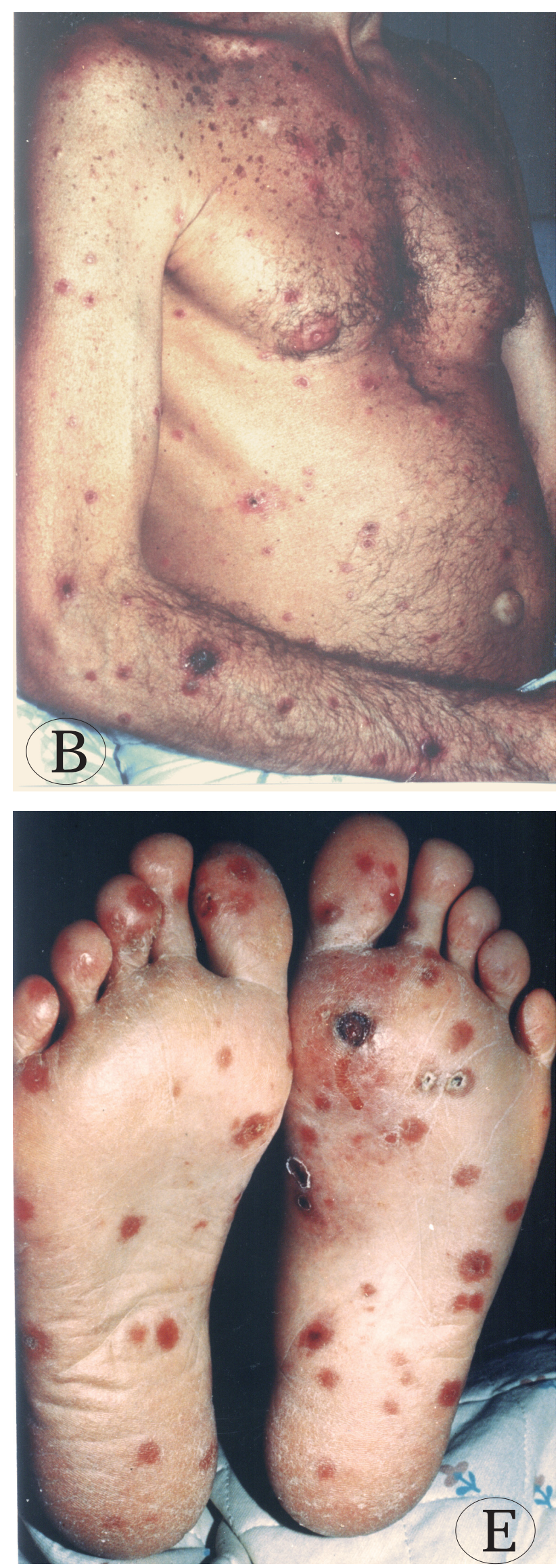

Figure 1 - Multiple skin lesions of lues maligna in an HIV-infected patient: A) papulopustular lesions and necrotic ulcers over the face; $B$ and C) trunk; D and E) extremities. 
plaques and nodules, some with a necrotic center, and ulcers covered by a dark brown crust, present in his face, trunk, and extremities, including palms and soles (Figure 1). A large fetid rupioid crusted ulcer was observed on his jaw. No mucosal lesions were seen. He had cervical lymphadenopathy, splenomegaly, and gynecomastia. The remainder of the physical examination was normal, including the neurologic system.

Laboratory investigations revealed. Hemoglobin, $10.1 \mathrm{~g} / \mathrm{dL}$; leukocytes, $3,000 / \mathrm{mm}^{3}$ (58\% granulocytes and 32\% lymphocytes); platelets, $63,000 / \mathrm{mm}^{3}$; erythrocyte sedimentation rate, $103 \mathrm{~mm} / \mathrm{hr}$. Levels of serum AST, ALT, bilirubin, and alkaline phosphatase were normal. Syphilis serology showed a VDRL titer of 1:64 and a positive Treponema pallidum hemagglutination (TPHA). Chest x-ray film was normal. The cerebrospinal fluid examination showed: 2 cells/ $/ \mathrm{mm}^{3}$; protein $45 \mathrm{mg} / \mathrm{dl}$; glucose 50mg/dl; VDRL 1:1; and TPHA positive.

Treatment was started with intravenous aqueous crystalline penicillin G 18 MU per day, preceded by a single dose of prednisone $60 \mathrm{mg}$. On the sixth day of treatment he had fever with rigors that defervesced over the next 36 hours. Blood cultures were negative. It was assumed to be a late JarischHerxheimer reaction. The response to penicillin was excellent and he was discharged from hospital after 14 days of treatment.

Three months after completion of therapy, he had gained $3 \mathrm{~kg}$, and was taking the antiretrovirals regularly. All skin lesions were healed, though some with residual scars. His $\mathrm{CD}^{+}$cell count was $297 / \mathrm{mm}^{3}$ ( $41 \%$ ) and HIV viral load was 670 copies/ml ( $2.8 \mathrm{log})$. VDRL test showed a titer of 1:2,048. The patient denied maintaining sexual relationships since hospital discharge. No specific treatment was provided. At 15 and 35 months later, the VDRL was 1:8.

\section{DISCUSSION}

Lues maligna was first described by Bazin (1859) and Dubuc (1864), who applied this term based on the bizarre clinical features and progressive course of this variant of syphilis ${ }^{14}$. During some decades, there was controversy about whether lues maligna was a severe variant of secondary syphilis or an early manifestation of tertiary syphilis; a question clarified by Haslund and Neisser in 1896-199714. In contrast to tertiary syphilis, the lesions of lues maligna are multiple, have a round or oval configuration, with no tendency to central healing, and exhibita lamellated, brown-black rupioid crust. Moreover, the early onset of necrotic ulcers in the disease is in contrast to the later occurring gummas of tertiary syphilis ${ }^{6}$. The criteria for diagnosis of lues maligna listed by Fisher et $\mathrm{al}^{6}$ include strongly positive serological test results, a severe Herxheimer reaction, and an excellent response to antibiotic therapy. In the past, serological anergia was one of the characteristic features of the disease, a concept no longer supported ${ }^{1022}$. Even taking into account the extensive clinical differential diagnosis of lues maligna, which includes pyoderma gangrenosum, vasculitis, lymphoma, leishmaniasis, leprosy, yaws, and mycobacterial or fungal infections, no other disease process could explain both the morphology of the lesions and the rapid involution with treatment 6 .

Our case showed the classical clinical picture of lues maligna, and had an excellent response to penicillin. AJarisch-Herxheimer reaction occurred late in the course of therapy, probably due to the use of prednisone preceding the first penicillin dose $\mathrm{e}^{21}$. The patient had a serologic response not previously described in malignant syphilis occurring in HIV-infected patients, or that is, the VDRL titer, which was 1:64 at presentation, increased to 1:2,048 three months after successful treatment. Gregori et al ${ }^{7}$ reported an HIV-infected patient with lues maligna - described as tertiary syphilis with lesions of early and advanced secondary syphilis - in whom the rapid plasma reagin ( $R P R)$ titer was 1:256 at presentation, raised to 1:8,192 one week later ( before therapy), and decreased to 1:32 eight weeks after successful treatment. Since a polyclonal antibody response is documented in some HIV-infected individuals, patients co-infected with HIV and T. pallidum may have a serological response with very high titers, which is common, or present persistently high titers despite antibiotic therapy ${ }^{20}$. Thus, high serological titers after treatment should not be viewed as therapy failure, but as a possible phenomenon. Even considering that falsely rising titers occur in individuals with previously treated syphilis, reinfection with T. pallidum should not be discarded.

The first cases of lues maligna in HIV-infected individuals were reported in 1987 by Rosenheim et $\mathrm{al}^{13}$, and in 1988 by Armignacco et $\mathrm{al}^{1}$, Schröter et $\mathrm{al}^{17}$, and Shulkin et $\mathrm{al}^{18}$. Since then, the number of case reports has increased, which might be related to better recognition or reporting ${ }^{15}$. However, it seems to represent an actual increase in the occurrence of this type of syphilis $^{45}$. In a German multicenter retrospective survey of 11,368 HIV-infected patients, active syphilis was reported in 151 (1.3\%) patients, 11 (7.3\%) of whom presented with malignant syphilis ${ }^{16}$. In Chandigarh, India, lues maligna was reported in $2 / 55$ patients with syphilis diagnosed from 1990 to 1999: one of three HIVinfected patients presented with lues maligna ${ }^{8}$. In Rio de Janeiro, at the Infectious Diseases Department of the Hospital dos Servidores do Estado, lues maligna was diagnosed in three HIVinfected individuals from 1986 to 2002, a finding that contrasts with a previous report of lues maligna occurring in 3/3,253 patients with acquired syphilis diagnosed at the Dermatology and Venereology Department of our Institution between 1948 and $1972^{14}$. All those reports reinforce the hypothesis that HIVinfected individuals are at risk for developing malignant syphilis.

It is still unclear why only a few T. pallidum-infected patients develop lues maligna. The progressive and destructive course of this type of syphilis might be due to an immunocompromised status of the host, a more virulent strain of T. pallidum, or even an excessive immune response ${ }^{2}$. However, it appears unlikely that there are T. pallidum strains of different virulence ${ }^{10}$, and an immune complex mediated mechanism is apparently not involved in the disease process ${ }^{9}$. Cell-mediated immunity seems to play an important role in the pathogenesis of syphilis, but the $\mathrm{CD} 4^{+}$ cell count is not the only determinant factor for the occurrence of lues maligna, since ithas been reported in HIV-infected patients with a $\mathrm{CD}^{+}$cell count of $24 / \mathrm{mm}^{3}{ }^{17}$ as well as in patients with 
$1,200 \mathrm{CD} 4^{+}$cells $/ \mathrm{mm}^{3}$. Qualitative or functional defects of both cell-mediated and humoral immunity are probably involved in the pathogenesis of malignant syphilis: the pathogenic interaction between HIV and Treponema pallidum both leading to an immunodeficiency state may reduce the immunologic response to treponemal infection through a decrease in cell-mediated immunity, macrophage functional defects, and possibly immunomodulation of the humoral immunity response ${ }^{19}$. The local immune response to $T$. pallidum may be critical to the development of clinical manifestations as well as to the clearance of spirochetes from infected tissues. However, relatively little is known about the local immune responses to T. pallidum in skin and other body sites, and virtually nothing is known about the subpopulations of immune cells in the lesions of patients with syphilis co-infected with $\mathrm{HIV}^{11}$.

Although the clinical manifestations and the course of syphilis may be altered in the presence of HIV infection, most HIV-infected patients with syphilis have typical disease manifestations. Clinical features of syphilis are protean, and the diagnosis of lues maligna should be considered in all HIV-infected individuals with ulceronodular skin lesions ${ }^{322}$. This approach might avoid unnecessary efforts or more complex investigations of other diseases occurring in these patients. As Witkowsky and Parish ${ }^{22}$ emphasized, a simple serologic test for syphilis can bring a case to a speedier and less costly conclusion.

\section{ACKNOWLEDGMENTS}

We gratefully thank Dr. Elizabeth Machado, Dr. Leon Claude Sidi and Dr. Fernando Luiz Lopes Cardoso, colleagues at the Infectious Disease Department, Hospital dos Servidores do Estado, for their comments.

\section{REFERENCES}

1. Armignacco 0, Antonucci G, Croce GF, Grillo LR, Valenzano L. Lue ed infezione da HIV. Considerazioni su un caso di sifilide maligna. Recenti progressi in medicina 79: 132-134, 1988.

2. Bahmer FA, Anton-Lamprecht L. Ultrastructural features of malignant syphilis and demonstration of Treponema pallidum. International Journal of Dermatology 22: 165-170, 1983.

3. Belda-Jr W, Dias MC, Zolli CA, Santos-Jr MFQ, Siqueira LFG. Ś́filis maligna precoce. A propósito de um caso. Anais Brasileiros de Dermatologia 65: 147-150, 1990.

4. Caumes E, Janier M, Janssen F, Feyeux C, Vignon-Pennamen MD, Morel P. Syphilis acquise au cours de l'infection par le virus de l'immunodéficience humaine. Six cas. La Presse Médicale 19: 369-371, 1990.
5. Don PC, Rubinstein R, Christie S. Malignant syphilis (Lues maligna) and concurrent infection with HIV. International journal of dermatology 34: 403-407, 1995.

6. Fisher DA, Chang LW, Tuffanelli DL. Lues maligna. Presentation of a case and a review of the literature. Archives of Dermatology 99: 70-73, 1969.

7. Gregory N, Sanchez M, Buchness MR. The spectrum of syphilis in patients with human immunodeficiency virus infection. Journal of the American Academy of Dermatology 22: 1061-1067, 1990.

8. Kumar B, Gupta S, Muralidhar S. Mucocutaneous manifestations of secondary syphilis in North Indian patients: a changing scenario? The Journal of dermatology 28: 137-144, 2001.

9. Kumar B, Muralidhar S, Das A. Malignant syphilis: an immunological puzzle. International journal of STD \& AIDS 9: 114-116, 1998.

10. Lejman K, Starzycki Z. Syphilis maligna praecox. A case report. The British Journal of Venereal Diseases 48: 194-199, 1972.

11. McBroom RL, Styles AR, Chiu MJ, Clegg C, Cockerell C, Radolf JD. Secondary syphilis in persons infected with and not infected with HIV-1: a comparative immunohistologic study. The American Journal of Dermatopathology 21: 432-441, 1999.

12. Menezes JA, Cunha RQ, Carvalho LM, Cruz MLS. Sífilis maligna precoce como primeira manifestação de AIDS - relato de dois casos. In: Resumos do XXXI Congresso da Sociedade Brasileira de Medicina Tropical, São Paulo, p. 302, 1995.

13. Rosenheim M, Brucker G, Leibowitch M, Niel G, Bournerias I, Duflo B, Gentilini M. Syphilis maligne chez un malade porteur d'anticorps antiVIH. La Presse Médicale 16: 777, 1987.

14. Rutowitsch MS. Sífilis maligna precoce. Anais Brasileiros de Dermatologia 55: 147-150, 1980.

15. Sands M, Markus A. Lues maligna, or ulceronodular syphilis, in a man infected with human immunodeficiency virus: case report and review. Clinical infectious diseases 20: 387-390, 1995.

16. Schöfer H, Imhof M, Thoma-Greber E, Brockmeyer NH, Hartmann M, Gerken G, Pees HW, Rasokat H, Hartmann H, Sadri I, Emminger C, Stellbrink HJ, Baumgarten R, Plettenberg A, The German AIDS Study Group (GASG) . Active syphilis in HIV infection: a multicentre retrospective survey. Genitourinary medicine 72: 176-181, 1996.

17. Schröter R, Näher H, Petzoldt D. Hautmanifestationen der syphilis maligna bei HIV-infektion. Klinische Beobachtungen an drei Fällen. Der Hautarzt 39: 463-466, 1988.

18. Shulkin D, Tripoli L, Abell E. Lues maligna in a patient with human immunodeficiency virus infection. The American Journal of Medicine 85: 425-427, 1988.

19. Tosca A, Stavropoulos PG, Hatziolou E, Arvanitis A, Stavrianeas N, Hatzivassiliou M, Stratigos JD. Malignant syphilis in HIV-infected patients. International Journal of Dermatology 29: 575-578, 1990.

20. TramontEC. Syphilis in adults: from Christopher Columbus to Sir Alexander Fleming to AIDS. Clinical Infectious Diseases 21: 1361-1371, 1995.

21. Tramont EC. Treponema pallidum (Syphilis). In: Mandell GL, BennettJE, Dolin R (eds) Principles and practice of infectious diseases, $5^{\text {th }}$ edition, Churchill Livingstone, Philadelphia, p. 2474-2490, 2000.

22. Witkowski JA, Parish LC. The great imitator: malignant syphilis with hepatitis. Clinics in Dermatology 20: 156-163, 2002. 